\title{
Politeness Theory Applied to the Teaching of the Imperative Mood in English as a Foreign Language Classes: A Textbook Analysis
}

Makeli ALDROVANDI

\begin{abstract}
This paper consists of five parts. Initially, the concept of Pragmatics is presented. Afterwards, a bibliographic review on Politeness Theory is done (Brown \& Levinson, 1987). Following that, the National Curricular Parameters (PCN) are analyzed as well as what they suggest to the teaching of a foreign language in Brazilian High Schools, regarding the competences to be developed by the students on this level, as well as the inclusion of the teaching of Foreign Language in a wider area of knowledge, named Language, codes and their technologies. The criteria that the Guide of the National Textbook Program (PNLD) uses to indicate the collections that may be adopted by the public schools in the country are verified as well. Based on the PCN and the PNLD Guide, an analysis of two textbooks is carried out. These textbooks are on the list that was approved by the Ministry of Education to be distributed to the schools. The analysis aims at verifying whether there is coherence between the PCN and the textbooks. We have come to the conclusion that, even though the textbooks have a great variety of activities which comprehend the abilities of speaking, writing, listening and reading, they still treat grammar as an element apart, without contextualization nor application to real life interaction. Finally, some suggestions are made about how to include Pragmatics, specifically, Politeness Theory in foreign language classes in High School, starting from what the textbooks themselves offer the students.
\end{abstract}

Keywords: Pragmatics, Politeness Theory, PCN, Textbook.

\section{Introduction}

This paper aims at analyzing how pragmatics is approached in two textbooks distributed by the Ministry of Education to public schools in Brazil. We analyze whether pragmatic aspects are mentioned during the lessons that are supposed to teach the Imperative Mood in English as a Foreign Language classes.

Two textbooks have been selected, both distributed by the Ministry of Education in the year of 2012, to be used in that year and the three years following that. We have selected the teaching of Imperatives because, according to Brown \& Levinson (1987), the speech act of commanding is the most face-threatening of all speech acts.

The core goal is to investigate what is taught when it comes to teaching Imperatives: only the structure or how to use it properly in different situations of conversation and language use. We also want to evaluate those two textbooks based on what the guidelines of the Federal Government to the teaching of a foreign language in Brazilian schools suggest. 
The paper is divided into five sections: Pragmatics, Politeness Theory, PCN Textbook Analysis and Suggestions on how to include Pragmatics in EFL classes.

\section{Pragmatics}

Language is a field with such a wide scope that it is necessary to divide it into small branches to be able to study all of it properly. Each branch has a different and specific view on one aspect of language. The scope of Pragmatics consists of studying language in a context taking into consideration the speaker and the hearer, mainly the intention of the speaker upon making an utterance. According to Rose \& Kasper, Pragmatics is the study of communication. They say:

Pragmatics is defined as the study of communicative action in its sociocultural context. Communicative action includes not only using speech acts (such as apologizing, complaining, complimenting, and requesting), but also engaging in different types of discourse and participating in speech events of varying length and complexity.

(Rose and Kasper, 2001, pag. 2)

It means that Pragmatics is concerned with several types of language use, regardless of its complexity or length. What differentiates Pragmatics from other fields such as Semantics is that what matters to the study of language is also how the hearer reacts to it, and not only what the speakers mean or what resources they use to achieve the desired meaning. Lo Castro says:

Pragmatics is an inherently functional perspective on language: by asking how a
speaker realizes an intended meaning through linguistic and nonlinguistic means,
the question represents a functional point of view by looking first at what the
speaker wants to do and then how it gets done via language. (Lo Castro, 2003, pag.11)

Still according to Lo Castro, Pragmatics has five specific features that must be taken into consideration when dealing with language through its perspective. The five features are:

Meaning is created in interaction with speakers and hearers.

Context includes both linguistic (co-text) and nonlinguistic aspects.

Choices made by users of language are an important concern.

Constraints in using language in social action (who can say what to whom) are significant

The effects of choices on coparticipants are analyzed.

(Lo Castro, 2003, pag.29)

These aspects are of extreme value to distinguish Pragmatics from other fields of Language study. There are two types of context: the linguistic one related to the text (also called co-text) and the non-linguistic one, related to other aspects such as who the speaker and hearer are, where they are, what is happening around them, what their intention is and others. The usage of one word or another is of great importance, it does not happen randomly. When the speakers use one word or form, they 
have a purpose for that and it must be given attention to. Not everything can be said everywhere by everyone: to Pragmatics, there are certain restrictions about language use: certain things only have true meaning and value if spoken by specific people at specific moments. And, finally, as mentioned before, the hearers play an important role: their reaction to what has been said is important to pragmatic studies.

Within Pragmatics, subfields have been developed with specific concerns related to language. One of them is Politeness Theory, the topic of discussion in our following section.

\section{Politeness Theory}

Within pragmatic studies, there are several theories. Among the best known is Politeness Theory. This theory was idealized by Brown \& Levinson in 1987 in their book Politeness: Some Universals in Language Usage. However, it had had its beginning earlier, with Grice's Cooperative Principle, which suggested that both hearer and speaker aim at achieving successful communication. According to Huang $(2007,25)$, the cooperative principle is summarized as "Make your conversational contribution such as required, at the stage at which it occurs, by the accepted purpose or direction of the talk exchange in which you are engaged".

Especially relevant to this theory is the concept of face. The concept of face is relevant because it is on the study of the face and the face wants that theory is built. According to O'Keefe et al. $(2012,63)$, the concept of face was taken from Goffman's research on politeness related to sociology. The term face appeared due to the English idiomatic expressions to lose face, which means to be embarrassed or to feel humiliated, and to save face, which is to avoid the loss of personal respect and reputation.

To Brown \& Levinson, the concept of face is defined as:

Thus face is something that is emotionally invested, and that can be lost, maintained, or enhanced and must be constantly attended to in interaction. In general, people cooperate (and assume each other's cooperation) in maintaining face in interaction, such cooperation being based on mutual vulnerability of face.

(Brown \& Levinson, 1987, pag. 61)

That is, face is the self-image that one has of oneself and expects to be respected by the other people with whom one interacts. Furthermore, according to the theory, there is a kind of implicit contract in human relations in which each person tents to cooperate with the other so that both faces are respected. Lo Castro clearly explains the concept of face adopted by Brown \& Levinson:

Face is a technical term to denote the public self-image all human beings wish to maintain. It includes emotional and social aspects, such as that one is honest, wellbehaved, clean and a member of particular groups and institutions in society. A person expects others to recognize and acknowledge their face needs.

(Lo Castro, 2003, p.110) 
According to the author, there are social and emotional aspects involved in the concept of face. The emotional aspects refer to the way one wishes to be treated as an individual, and the social aspects are those referring to how one expects one's face to be recognized due to one's social status in relation to others.

The concept of face is studied in terms of face wants and face threats. The face wants are the wishes of one person regarding his own self-image. It is in relation to the face wants of each person that the contract among the speakers is done. This contract of respect to the respective faces of speaker and hearer is called politeness. Lo Castro says:

It is generally believed that, in everyday social interactions, people act in such a way as to show respect for the face wants or needs of their conversational partners. It is a story, simply, of "you respect my public self-image and I'll respect yours". The use of language to carry out social actions where mutual faces wants are respected, can be labeled linguistic politeness.

(Lo Castro, 2003, pag.111-112)

Thus, politeness is the respect to the other person's face wants. Yule (1996) describes politeness as the awareness to the other person's face. This awareness includes the notion of closeness or distance needed in the dealing with another individual: closeness to people with whom one has certain familiarity or distance from people who have a higher social status, or belong to a higher rank in hierarchy. To Yule:

Politeness, in an interaction, can then be defined as the means employed to show awareness of another person's face. In this sense, politeness can be accomplished in situations of social distance or closeness. Showing awareness of another person's face when that other seems socially distant is often described as terms of respect or deference.

(Yule, 1996, pag. 60)

The disrespect to the interlocutor's face is shown through a face threatening act-FTA. A FTA can take place by means of inadequate language to the social status of the person, by means of impositions, or even questionings. Sometimes, a FTA is necessary, for example, when one asks someone to unblock their view at a movie theater. However, in situations as that, Politeness Theory proposes the Face Saving Acts - FSA, that are manners by which the threat to the other individual's face can be diminished. Indirectness is one of the face saving acts cited by Brown \& Levinson in their book. Lo Castro (2003) suggests that there are several elements underlying indirectness that must be taken into account by the speaker when opting for being indirect. Among them, the power existing between speaker and hearer, the social distance, duties and obligations, and others. This means that there are specific moments and situations to be indirect when speaking. To Lo Castro:

Once the speaker decides to use indirectness, a number of parameters are involved in the calculation of indirectness: relative power between speaker and hearer, social distance, weight of imposition, rights and obligations, and the degree of involvement in the interaction by the participants. Note that all of these parameters are relative and negotiated in the course of the interaction. The choice made by the 
speaker is manifested in the linguistic code (address forms, honorifics, indirect speech acts, passives, formulaic language, and forms of mitigation) and paralinguistic means, specifically through prosody.

(Lo Castro, 2003, pag.121)

It can be noticed, then, that Politeness Theory is quite complex, having many elements underlying the simple cordiality among people. Brown \& Levinson conceive two types of politeness: negative and positive politeness. Positive politeness consists of creating closeness between speaker and hearer, sympathy, according to Huang (2007). To Huang, negative politeness tends to keep the distance between speaker and hearer, showing deference in dealing with the hearer. It is important to point out, though, that negative politeness does not consist of being impolite. On the contrary, it consists of attempting to minimize the disturbance caused by the speaker on the hearer.

So as to make it possible to determine what type of politeness must be used, the speaker should be aware of the face of the other individual, and his own in that specific interactive situation. To Brown \& Levinson, there are two types of face: the positive and the negative face. According to Yule $(1996,62)$, the positive face is "the need to be accepted, even liked, by others, to be treated as a member of the same group, and to know that his or her wants are shared by others". On its turn, the negative face is to Yule $(1996,61)$ "the need to be independent, to have freedom of action, and not to be imposed on by others".

The strategies of politeness, whether negative or positive, should meet the type of face of the hearer. To Yule (1996, 65-66), the strategies of positive politeness may be the appeal of the speakers towards an objective that is common between them him and the hearer, or even a call for the friendship existing between them. Regarding negative politeness, the strategies correspond to the use of appropriate linguistic forms, as modals, indirectness through questions, and others. Examples of positive and negative politeness might be, respectively:

a) Since you are a friend of mine, you will not mind doing me a favor.

b) I do not mean to be rude, but, could you possibly do me a favor, please?

It is possible to see, then, how important it is for the speaker to be aware of the face wants of his listener so that the communication can achieve its purpose. Effective communication, therefore, goes beyond correct grammar and pronunciation. We follow now to the study of the guidelines present in National Curricular Parameters $(P C N)$ to the teaching of foreign languages in Brazilian High School, as a start to our analysis on the textbooks.

\section{National Curricular Parameters (PCN)}

The National Curricular Parameters (PCN), of 2000, suggests that the teaching of foreign languages has restored its importance in the education of the students. According to PCN (2000, 25), "the Foreign Languages take on the condition of being an indissoluble part of the set of essential 
knowledge that allows the student to approach several cultures and, consequently, promote his integration in a globalized world","

Upon presenting some of the history of the teaching of foreign languages in Brazil, the PCN criticize the teaching of the language in a mechanic and decontextualized way, based only on the memorization of grammatical forms. The PCN include the foreign language within a wider area named Language, codes and their technologies. By doing so, it is suggested that an interdisciplinary approach is taken, leaving the insulation of the subject behind.

Therefore, the objective of teaching a foreign language at school is not only reading, speaking, understanding and writing correctly in the target language, rather to provide the student with the possibility of "reaching a level of linguistic competence able to allow him access to information of various types, while contributing to his general education as a citizen" (PCN, 2000,26). This means that the grammatical rules must not be taught only with the objective of knowing them, but so as to allow the student to view himself as a citizen capable of communicating "appropriately in different situations of everyday life" ${ }^{3 "}$ (idem).

The PCN also present what the competences which must be developed by the students in relation to the Foreign Language in High School are.

a. Knowing how to distinguish linguistic variants;

b. Choosing the register record which is appropriate to the situation in which the communication takes place;

c. Choosing the word which best reflects the idea which one intends to convey;

d. Understanding in what way determined expression may be interpreted in terms of social and/or cultural aspects;

e. Understanding to what degree the utterances reflect the way of being, thinking, acting and felling of the one who produces them;

f. Utilizing the mechanisms of cohesion and coherence in the production in the Foreign Language (orally and/or written). All texts referring to production and reception in any language are ruled by general principles of coherence and cohesion and, thus, we are able to understand and be understood.

g. Utilizing verbal and non-verbal strategies to offset for failures in communication (such as the fact of not remembering, at the moment, a grammatical or lexical form), in order to promote effective communication and achieve the effect intended (speaking slowly, or emphasizing certain words, purposely to obtain certain rhetorical effects, for example). ${ }^{4}$

1Author's translation of (check all spacing in the footnotes) "as Línguas Estrangeiras assumem a condição de serem parte indissolúvel do conjunto de conhecimentos essenciais que permitem ao estudante aproximar-se de várias culturas e, consequentemente, propiciam sua integração num mundo globalizado”.

2Author's translation of "atingir um nível de competência linguística capaz de permitir-lhe acesso a informações de vários tipos, ao mesmo tempo em que contribua para a sua formação geral enquanto cidadão".

3Author's translation of “de maneira adequada em diferentes situações da vida cotidiana”.

4Author's translation of :

- Saber distinguir entre as variantes linguísticas.

BELT Journal • Porto Alegre • v.5 • n.1 • p. 40-52 • janeiro/junho 2014 
(PCN, 2000, pag. 28-29)

The PCN make it clear that the students must achieve not only a satisfactory grammatical competence, but also "have a good grasp of sociolinguistic competence, of discursive competence and also of strategic competence" ${ }^{5}$ (PCN, 2000, 29). That is, knowing how to use a certain utterance in a specific context. Having become acknowledged with the view on the objective of teaching a foreign language and what competences the students are expected to develop, we move on to the textbook analysis to assess whether these objectives and competences are being taken into account in the lessons presented in the textbooks.

\section{Textbook analysis}

Nowadays, Brazilian public high schools can count on textbooks for the teaching of a foreign language. According to the website of National Fund to the Development of Education (FNDE- in Portuguese), the National Textbook Program (PNLD - in Portuguese) started to distribute, free of charge, the Foreign Language textbooks to High School students in the year 2009. Still according to FNDE, the textbooks are classified as reusable or consumable. Reusable are those books which must be returned to school at the end of the school year, in order to be used by another student the following year, and consumable are those which belong solely to the student and, therefore, do not need to be returned. The foreign language textbooks are considered consumable.

Even though the PNLD distributes the books to schools, it is the task of the teachers to select the textbook to be used, along with their peers of the same area, among the textbooks that have been approved by PNLD. The Guide PNLD (2012), for example, lists and presents reviews on ten

- Escolher o registro adequado à situação na qual se processa a comunicação.

- Escolher o vocábulo que melhor reflita a ideia que pretenda comunicar.

- Compreender de que forma determinada expressão pode ser interpretada em razão de aspectos sociais e/ou culturais.

- Compreender em que medida os enunciados refletem a forma de ser, pensar, agir e sentir de quem os produz.

- Utilizar os mecanismos de coerência e coesão na produção em Língua Estrangeira (oral e/ou escrita). Todos os textos referentes à produção e à recepção em qualquer idioma regem-se por princípios gerais de coerência e coesão e, por isso, somos capazes de entender e de sermos entendidos.

- Utilizar as estratégias verbais e não verbais para compensar falhas na comunicação (como o fato de não ser capaz de recordar, momentaneamente, uma forma gramatical, ou lexical), para favorecer a efetiva comunicação e alcançar o efeito pretendido (falar mais lentamente, ou enfatizando certas palavras, de maneira proposital para obter determinados efeitos retóricos, por exemplo).

5Author's translation of "possuir um bom domínio da competência sociolinguística, da competência discursiva e da competência estratégica".

BELT Journal • Porto Alegre • v.5 • n.1 • p. 40-52 • janeiro/junho 2014 
textbooks so the teachers can select the one that best adapts to his school. Three out of these ten books are for teaching Spanish and seven are for teaching English. Among the textbooks listed that year, are the two selected to this study.

Besides the reviews, the PNLD Guide (2012) presents some criteria to be adopted by the teacher during the selection of the textbooks. Among the criteria, the ones we will take into consideration in this study are the ones belonging to block VII:

\section{BLOCK VII: CONCERNING LINGUISTIC ELEMENTS, THE COLLECTION:}

25. Does it propose a systematization of linguistic knowledge, as from varied discursive practices?

26. Does it address linguistic variations of the foreign language?

27. Is it free from wrong metalinguistic information or simplifications that might conduct to mistakes?

28. Is it free from mistakes and inadequacies inadequateness to the usage of the foreign language? ${ }^{6}$

(Guide PNLD, 2012, pag. 14)

We will analyze, particularly, the item 25: "Proposes a systematization of linguistic knowledge, as from varied discursive practices". We have selected this item for it deals with the effective use of a foreign language to communication.

The PNLD should comply with the PCN upon suggesting textbooks, once it is the PCN that present the paths to be followed by the teachers in their classes. Hence, the main focus of the analysis of the textbooks will be the coherence between the competences to be developed by the students, according to the PCN, the items to be evaluated by the teachers, according to the PNLD Guide upon selecting a textbook, and what is actually offered by the textbook.

Among the competences to be developed by the students, according to the PCN, the ones selected to this analysis are $b, d$ and $e$, listed below.

b. Choosing the record which is appropriate to the situation in which the communication takes place;

d. Choosing the word which best reflects the idea which one intends to convey;

e. Understanding to what degree the utterances reflect the way of being, thinking, acting and felling of the one who produces them;

6Author's translation of :

"25. Propõe a sistematização de conhecimentos, a partir do estudo de situações contextualizadas de uso da língua estrangeira?

26. Aborda variações linguísticas no uso da língua estrangeira?

27. É isenta de informações metalinguísticas equivocadas ou simplificações que possam conduzir ao erro?

28. É isenta de erros e inadequações no uso da língua estrangeira?"

BELT Journal • Porto Alegre • v.5 • n.1 • p. 40-52 • janeiro/junho 2014 
We understand that these items have close relationship with the one selected from the PNLD Guide, for dealing with the usage of language in real life situations and, also because they approach the intention of the speaker upon making an utterance. The textbooks chosen to be analyzed belong to the ON STAGE and UPGRADE collections, published by Ática and Richmond, respectively. Each textbook will be analyzed at a time and the criteria will be applied to each of them. The grammar topic elected to be investigated is the Imperative Mood. As seen in the section Politeness, one of the speech acts considered to be the most face-threatening one is the speech act of commanding. Therefore, it is of great relevance to examine whether the textbooks mention ways to minimize this face-threatening act. Based on what the PCN suggest and on what the PNLD guide determines as relevant for the teacher's choice, we will investigate if the textbooks present:

1. Connection between grammar topic and proper usage in real life conversational situations;

2. Information on the difference in meaning achieved by the usage of one grammar form over another;

3. Reflection on the impact of the speaker's choice for some specific grammar form on the hearer.

4. Application of the grammar topic to varied linguistic practices and situations.

\subsection{On Stage}

The first textbook presents the Imperative Mood, starting with a statement taken from the text studied in the unit. The text itself does not use many imperative sentences: the one chosen is actually the only one. The explanation on the topic is given in Portuguese and it is basically structure information. However, there is a note that says "Another way (softer and more polite) to present suggestions about actions that include the person who speaks is using let's+ the infinitive of the verb, without to.". After this brief explanation, there is an exercise in which the students must fill in the blanks with some verbs given. The verbs are already in the Imperative Mood, using affirmative and negative, and let's. The sentences that are supposed to be filled in are all related to the theme of the unit, but none of them belongs to another text. By the end of the exercise, there is a note instructing the students to seek more information about the grammar points presented in the unit in a Minigrammar at the end of their textbook, however, there is nothing else related to Imperative.

ON STAGE does not meet most of our criteria. Firstly because it does not make a connection to possible real life usages to the topic, it simply shows the structure. Although it does present a way

7Author's translation of "Uma outra forma (mais suave, polida) de apresentar sugestões sobre ações que incluem a pessoa que fala é usar o let's + o infinitivo do verbo, sem to." 
to lessen the face-threatening act of command suggesting that the students use let's instead of using the simple affirmative imperative, it does not make any reference to the change in meaning that this substitution would cause, nor does it explain when and with whom they might use that mood without seeming rude, which is our criterion number three, about the impact caused on the hearer by their using the imperative. Finally, the textbook does not apply the grammar topic to real life practices. It only asks students to perform a structure-based activity, which does not verify the comprehension of the proper usage of imperative. Even though ON STAGE has a varied range of activities which intend to develop all four skills (listening, reading, writing and speaking), grammar is not taught in context, it is a part which is detached of the unit, having as the only link the theme of the unit, used in the exercises.

\subsubsection{Upgrade}

Analyzing the second textbook, UPGRADE, we see that, as well as the first book, the grammar topic of Imperative Mood is presented in a section apart. However, differently from the previous book, it does not have any connection with the theme of the unit at all; it does not even use the same theme in the presentation of grammar. Here, as in the first book, the explanation about Imperatives is given in Portuguese, focusing on structure. It does, however, present a section called Use. In this section, the explanation goes as follows:

- Expressing a command ${ }^{8}$ : Help your mom in the kitchen, Audrey. She's late with lunch.

- Making requests ${ }^{9}$ : Ask David to download the video about e-commerce spending.

- Giving instructions ${ }^{10}$ : Press the button before you use the equipment.

After the explanation and the examples, there is an exercise which focuses on structure, as the first textbook. In this exercise, students are supposed to rewrite the sentences in the imperative form, according to the example given.

Similarly to the textbook ON STAGE, the textbook UPGRADE does not meet our criteria. The grammar topic is presented by itself, without any instructions on how to use it properly in real life conversations. The criteria number two and three, which deal with meaning and the hearer are not even mentioned. The examples given are not related to any context, thus, it seems that the Imperative Mood might be used in all contexts and towards any person the students might get in touch with. To conclude, the textbook does not suggest, in this section, applications to real life practices. The only practice is structure-related. However, on the following pages, there is a section named Language in action. In this section, there is an exercise related to Imperative Mood. In the exercise, students are

8Author's translation of: Expressar uma ordem

9Author's translation of: Fazer pedidos

10Author's translation of: Dar instruções

BELT Journal • Porto Alegre • v.5 • n.1 • p. 40-52 • janeiro/junho 2014 
supposed to listen to a text about cell phone etiquette and must classify the statements as true of false, according to what they hear. All the statements are in the Imperative Mood. This suggests that there is an intention to apply the structure to a real life experience: an etiquette manual, in this case. However, again, the specificity of the situation is not clear. Again, it might appear to the students that it is accepted to use the Imperative Mood regardless of the situation.

\section{Suggestions on how to apply Politeness Theory in EFL classes}

This section of the article aims at suggesting some improvements that could be made in both textbooks analyzed so they would comply with what the PCN take as ideal to the teaching and learning of a foreign language in Brazilian schools.

Firstly, both of them should approach Politeness Theory in regards to what is acceptable and what is not in specific real life situations in terms of usage of Imperative Mood. Teaching structure has its importance, since the students must be acknowledged with how to say something in a language that is not their own, as it should be in their mother tongue. However, focusing only on structure will not make students able to handle and to communicate properly in more formal situations with people they are not familiar with. This type of scenario demands a more formal and less imposing language. Thus, the teaching of appropriateness is as important as the teaching of structure.

Secondly, both textbooks have a great variety of activities that span all four skills that should be developed in EFL classes. Therefore, these activities should be better explored. Furthermore, both textbooks have their units divided into themes. Those themes should be taken into consideration throughout the unit. Based on this idea, some activities are suggested bellow.

The textbook ON STAGE has in unit three, the unit that presents Imperative Mood, as its core theme Nature. ON STAGE presents the Imperative Mood in its unit three. The core theme of this unit is Nature. The main text is about the importance of preserving trees so the humanity may have a better quality of life. Students could be asked to design posters that demand preservation of nature as if they were participating in a parade of Green Peace. That way, they would both practice imperatives in a possible real life situation and develop their sense of citizenship, which should also be developed at school. In contrast, students could be asked to write an email directed to someone who belongs to a higher rank in hierarchy or is not familiar with them, and demand that they preserve the environment. This is a good example on how inappropriate it would be to give direct orders to someone, when we want them to join our ideas of citizenship. This could be a positive politeness strategy: once they want the person to agree with their movement of protection of nature, they would want to create some closeness with the person, and giving direct commands does not seem to be a good strategy to bond with someone.

In relation to $U P G R A D E$, the unit which develops the Imperative Mood is unit number three as well. The core theme is Technology. Since they have a listening activity about cell phone etiquette 
as language work, students might be asked to create an etiquette manual to social networks. This would probably catch their attention because social networks are very popular among teenagers and, as the foreign language has been categorized into the area of Languages, codes and their technologies, this would be a good moment to promote an interdisciplinary activity. In order to understand that what we say and how we say it has an impact on our hearers, they could also be asked to imagine that someone has posted something offensive on their social network page which displeases them a lot. Even though they are not very close to this person, they must ask him to delete the post. They should be shown that the best way to do that, without offending the other person so much, is not demanding it directly or rudely, but in a way that would make them do it without taking it as a challenge to their freedom of expression. Here, the strategy would be one of negative politeness. The students do not want to seem as if they were reaping the other person's freedom of expression, so, they would have to maintain the distance between them and the target person. The command that he delete the post should be so as to not make the person think they do not recognize his right to posting whatever he wishes.

\section{Conclusions}

By analyzing the guidelines of the teaching of foreign languages in Brazil and the guide for the teachers on how to make a choice among the textbooks suggested by the Ministry of Education in Brazil, we could notice that there is a gap between what is referred to as ideal and what, in fact, is presented by textbooks.

It is a great concern to the PCN that the students of Brazilian High Schools are able to learn a foreign language so they can communicate properly, and also acquire information so they can become better citizens. The guidelines recommend that grammar be taught in a context and not isolated, and also that students learn, not only structure, but the impact that their choices, be them vocabulary or grammar, will have on the hearer. The textbooks analyzed do not meet those criteria.

Although they are not simply a compilation of grammar explanation and exercises, but bring a wide range of diverse activities, when it comes to grammar, they fail to present it as something which is part of a language. Presenting grammar apart from reading, writing and other skills makes it difficult for students to see the connection between grammar and language. Simple changes should be made so that grammar is incorporated into the units. It is not a problem to emphasize language structure; students must learn structure in order to communicate, but they must also see that the structure is not empty: choosing one verbal mood over another, one way of saying something over another, will make a difference on how their meaning would be conveyed.

If students are not taught to see the usage of what they learn, they will simply think of it as unimportant, and only memorize empty rules in order to fill in the blanks of a test and forget it all afterwards. Pragmatics plays an important role here. It is the field that deals with real communication, between speakers and hearers in real contexts (or possible ones in the case of EFL classes). 
Effective communication is accomplished not only by using correct forms, but appropriate forms as well. Making pragmatic mistakes, such as giving a direct command to someone of higher level of hierarchy, is as negative as making a grammar mistake. Taking into account the concepts of Politeness Theory, the face of the speakers would be "lost" by making such an error: they he would not only threat their hearer's face by imposing a command, but his own face would suffer damage, once he would be viewed as a rude individual.

\section{References}

MEC. Fundo Nacional de Desenvolvimento da Educação (FNDE) Available at: http://www.fnde.gov.br/programas/livro-didatico/livro-didatico-historico. Accessed on 27 April, 2014.

MEC. Guia do Programa Nacional do Livro Didático (PNLD) Available at: http://portal.mec.gov.br/index.php?option=com_content\&view=article\&id=12389\&Itemid=1129 Accessed on 27 April, 2014.

MEC. Parâmetros Curriculares Nacionais, 2000. Available at: http://portal.mec.gov.br/seb/arquivos/pdf/14_24.pdf. Accessed on 27 April, 2014.

AGA, Gisele (2010). Upgrade - Ensino Médio. Vol. 1. São Paulo: Richmond educação.

BROWN, P.; Levinson (1987). Politeness: Some Universals in Language Usage. Cambridge: Cambridge University Press.

HUANG, Yan (2007). Pragmatics.Oxford University Press. Oxford.

LO CASTRO, Virginia (2003). An introduction to pragmatics: social action for language teachers. The University of Michigan Press.

MARQUES, Amadeu (2010).On Stage - Ensino Médio. Vol. 1. São Paulo: Ática.

O'KEEFE, Anne; CLANCY, Brian; ADOLLPHS Svenja (2012). Introducing pragmatics in use. Routledge. London.

KENNETH R, Rose; Kasper, Gabriele (2001).Pragmatics in language teaching. Cambridge University Press. New York. $1^{\text {st }}$ edition.

YULE, George (1996). Pragmatics. Oxford University Press. 